\title{
CAUSES OF VAGRANCY AND ME'THODS OF ERADICATION
}

To what extent is vagrancy due to causes which can be speedily remedied? In seeking an answer to this question, the writer, during the winter of 1902-1903, made an investigation of the life histories of a large number of men at the Wayfarers' Lodge of the Philadelphia Society for Organizing Charity. He has also spent several weeks as a tramp and beggar in the cheap lodging houses and missions of London and Philadelphia. Conferences with police officers and others dealing with the question have furnished further opportunity to study the causes leading to vagrancy and the influence of social institutions upon the problem.

Vagrants may be divided into four classes:

I. Those who are really in search of work, and not merely "looking for work." Of this class the following is a typical case: F. J., 18 years old, has worked as bell boy in clubs in New York, where he has only an uncle who cares little for him. Having lost his job when a new steward'was appointed, he started to tramp till he could get another place.

2. "Hobo mechanics," who can secure employment at good wages most of the year, but spend their money in drink and high living. They are often employed at seasonal trades, so would have to have more than one to be occupied during the entire year. Typical case: L. P., 40 years of age, learned carriage painting when 16 , began to drink at 18 , and has been spreeing off and on since. Has earned $\$ 4.50$ per day, and on several occasions spent over $\$ 200.00$ on a single debauch.

3. Men with whom the plea of "looking for work" is merely an excuse for wandering and begging. Typical case: N. M., 26 years old, hand and limb slightly palsied by some accident. He gets permission from the police of many cities to sell pencils and says he is trying to get home. He often makes $\$ 2.00$ a day begging.

4. "Yeggmen." A class of criminal mendicants who beg, steal or commit petty depredations as occasion offers. Typical case: A. N., 35 years old, lost a leg on the railroad, and has begged for several years in New York, serving several short terms there. Was

[445] 
found to be "feeler" for a gang of safe-crackers operating in Philadelphia-locating safes for them while begging and planning the raid.

\section{Objective Causes of Vagrancy.}

I. Unwise philanthropy.

I. Religious missions without a work test. Many so-called religious missions foster the lowest type of tramp, the "mission bum," by putting the premium of money gifts or lodging upon professions of conversion.

2. Indiscriminate giving of alms. This is a more widespread and dangerous form of demoralization, and the most selfish way of evading responsibility under the pretence of generosity.

3. Caring for families of married vagabonds. This system of charity relieves the husband and father of all responsibility, and encourages him in tramping when his earnings are most needed at home.

II. Bad systems of public relief.

I. The open-door almshouse. Such relief enables vagrants to pass winter without labor and to renew their irresponsible wanderings in the spring. A vagrant in Boston who was recently shown to have been thirty-four times within seven years sent to jail or fined by the court, spent all his winters in the almshouse.

2. Careless outdoor relief. Without investigation this tempts the improvident to wander, and invariably attracts him from a more rigid régine.

III. Faulty municipal administration.

I. Methods of licensing small peddlars. Granting licenses to crippled and blind to peddle small wares practically licenses them to beg and starts many, especially cripples, on a life of vagabondage.

2. Lax enforcement of laws against begging. The failure of the police in most cities to arrest beggars enables vagrants to secure their living and traveling expenses.

3. Free police station lodgings and "over winter" sentences. This system corresponds in its effects to the missions without a work test, and the open-door almshouse, and vagrants feel they have a right to the help of the police.

4. Lack of proper places of detention for boys. Placing young boys in the same cells or even prisons with hardened vagrants and 
criminals is an active and vicious way of manufacturing vagrants and criminals.

5. Inadequate supervision of common lodging houses. Chicago, with 200 common lodging houses, Baltimore with I13, New York with 104, and Philadelphia with 106, to cite a few important cities, lack any adequate supervision of these moral oubliettes. The vagrant can in most cities easily pick up Io or 15 cents, the price of a lodging, and if he wishes to avoid the police, can lose himself in any one of a score of cheap lodging houses.

IV. Transportation.

I. Stolen. If stealing rides could be prevented, one effective blow would be given to vagrancy. Out of 19,438 men arrested for stealing rides, by police officers of the western division of the Pennsylvania Railroad from 1899 to $I 902$, all but 532 were professional tramps. Tramp camps along the main lines are disastrous agencies for enticing young boys into vagabondage. Railroad police often experience difficulty in securing conviction of trespassers by the courts along their lines, on account of the expense to local taxpayers of additional prisoners.

2. Free and half-fare. The practice of public officials or officers of private charitable societies of "sending on" applicants free or on half-fare, without investigation, encourages vagrants of the so-called respectable type as well as the ordinary tramp.

V. Lack of uniformity in legislation and enforcement on social subjects. This is notably true of laws on vagrancy and treatment of dependents and delinquents. Wife desertion is an offense and extraditable in only a few states. The vagrant naturally drifts into states where he knows conditions are most conducive to his habit of life.

\section{Subjective Causes of Vagrancy.}

I. Lack of employment due to following causes:

I. Drink. This is admittedly frequently only a secondary cause, but it is impossible to discuss here why men drink, and condoning the habit does not qualify drunkards for work.

2. Inability to work with others and under direction. Many skilled workmen have tempers uncontrollable in proportion to their appreciation of their skill. On slight provocation they throw up a job, and drift for a long time before securing as good employment. 
3. Licentiousness. With increased demand for high-grade labor the man whose mental keenness is blunted is thrown out of work first, and finds it hardest to reinstate himself.

4. Laziness. No amount of euphemism can cover this cause. It applies to piece-workers as well as time-workers. "There is hope for the vicious man, none for the lazy."

II. Personal traits.

I. Lack of thrift. Single men earning $\$ 9.00$ to $\$ 15.00$ a week for a large part of the year claim they cannot save anything from that, though they often spend one-third of their earnings on drink.

2. Pride. Men who leave home in good condition, and fail to get employment, will starve while wandering, or beg, rather than return to the ridicule of their friends and relatives.

3. "Wander lust." An indefinable and irresistible desire to "see the country."

III. Desire to escape justice.

I. Deserting husbands and petty criminals as well as those "wanted" by the police, are anxious to cover their tracks and be lost from detection by constant wandering.

Suggested Measures of Reform.

I. Municipal.

I. Licenses to peddle small wares. These should be issued only to those whose record shows that they really wish to peddle legitimately.

2. Schools for the blind and crippled. Every large city should maintain institutions to teach blind and crippled children and adults some legitimate trade or occupation at which they may earn a living. Attendance should be compulsory, the city furnishing means of living if necessary.

3. Wayfarers' lodges. Adequate provision should be made for every respectable homeless man to secure his board and lodging for a limited time while looking for remunerative employment, in return for three or four hours work daily. This will involve in all cities of over 50,000 a Wayfarers' Lodge under private or public management, with compulsory bath and medical exaimnation. In cities of under 50,000 a department of this lodge should be maintained entirely distinct for boys under eighteen. The treatment given them, while 
kind, must be sufficiently firm not to encourage the "wanderlust." In cities of over 50,000 the work of the Juvenile Court should include a detention room, where boys under eighteen must be sent.

There should be connected with the lodge, in the larger cities at least, some man who will take a sane and sympathetic interest in the men who come to the lodge. By no other method can the first class of vagrants be so effectively restored to natural relations, while it provides opportunity by moral suasion for the second class to reinstate themselves.

"By sending the worthy displaced laborer and willing but ignorant and discouraged country boy to paid employment, the sick and disabled to dispensaries, hospitals and homes, and the criminal to the House of Correction, it prevents the exploitation of the unfortunate by municipal authority, or the equally harmful exploitation of the municipality by corrupt loafers and vagabonds." There must be thorough differentiation in treating the several classes. The existence of such an institution abolishes every vestige of excuse for police station lodgings.

The most conspicuous effect of the result of a municipal lodging house is illustrated by the experience of Chicago. During Igor the number of homeless men and boys lodged in the police stations of Chicago was 92,59I. During I902 the number lodged at police stations was 5,740. During I902 the number lodged at the municipal lodging house was 11,097 . Decrease of the number of homeless men and boys lodged at the expense of the city in 1902 as compared with Igor, 75,754 .

For smaller towns a simple building with a few cords of wood, saws and saw-horses suffices. The town of Sherborn in Massachusetts, with a population of 1500 , established such a place in 1897 , at an expense for tools of $\$ 10.00$, and reduced the number of tramps visiting the city from 1844 in that year to 31 in $1901-a$ period of four years.

Every mission which furnishes lodging must also be induced to establish a work test.

4. Supervision of common lodging houses. These should be supervised by the building, health and police authorities, and licensed by the police. A high standard of cleanliness and sanitation should be maintained for the double purpose of restraining the decent 
element of patrons from degenerating, and compelling the worst element to improve themselves.

Boston has model health regulations. Every new applicant for public lodging is required to take a shower bath. A new applicant is interpreted to mean a person who has not been lodged at the same place the night before. A lodger may not be lodged for more than seven consecutive nights without taking a shower-bath. No person may retire or sleep in his day clothing. The means for light and ventilation must be satisfactory to the Board of Health and beyond the control of lodgers.

Lodging-house keepers should also be required to keep a record of the time of arrival and departure of every lodger, this record to be open at all times to the inspection of the police. Every building in cities of over 25,000 inhabitants, not licensed as an inn, in which ten or more persons are lodged for a price for a single night of 35 cents or less-in manufacturing cities, 50 cents or less-for each person should be deemed a public lodging house. Officers of the three supervisory authorities should be allowed free access to any part of a public lodging house at any time. Any keeper violating any of the regulations of the authorities licensing his house, should be heavily fined and his license revoked. These regulations should extend in toto to all missions and religious shelters.

5. A mendicancy squad. Every city of 50,000 or over should have at least one plain-clothes policeman to arrest beggars and vagrants; cities of over 200,000 should have a squad of several such officers, who should periodically visit the lodging houses, missions and religious shelters, and arrest inmates who cannot give a good account of themselves on charges of either drunkenness or vagrancy.

To 1llustrate: In the latter part of 1903 the police raided the lodging houses of Boston, including the Salvation Army shelter, and I04 men were taken. Forty-four were released, giving a satisfactory account of themselves; 2I were discharged by the court; 2 I were committed to the State Farm ; 9 were sent to jail ; 4 were sent to the Massachusetts Reformatory; 3 were released to probation officers; I fugitive from justice was returned to the proper authority: I was a deserter from the Navy.

Boston lodging houses, moreover, have been more carefully supervised than those in most cities. 
The mendicancy squad should see that the full term of sentence imposed is served. The mere act of applying for relief by an ablebodied man who cannot show that he has been legitimately employed within a reasonable time preceding, or prove that his lack of employment is not due to his own unfitness, should be sufficient grounds for sending him to a state fartn as a vagrant and mendicant.

6. Campaign against indiscriminate alms-giving. After provision for all classes of beggars is made, a vigorous educational campaign should be conducted to show the injustice of indiscriminate alms-giving.

II. State reformatory measures.

I. Institutions to teach trades to the blind and crippled. Every state should mantain institutions similar to those advocated for the larger cities, in which blind and crippled children and adults should be taught a trade or occupation. Attendance should be compulsory.

2. State farms. Every state should have a State Farm, to which vagrants should be committed and compelled to work on the farm or at some trade. If their labor is profitable their net earnings should be sent to their families. The Massachusetts State Farm has not yet been able to meet expenses by the sale of produce.

Men should be committed on an indeterminate sentence and be entitled to release on probation after a period of time determined by the number of their commitments. The probationary release should be upon the condition (as provided in the rules relative to release of prisoners on probation from the Massachusetts State Farm) that the holder of the permit to be at liberty does not return to his former habits of vagrancy and dissipation. To be seen entering a saloon or disorderly house should be sufficient reason for recommitment to the State Farm.

Connected with the State Farm should be an institution for inebriates, to which confirmed drunkards should be committed and from which they should be discharged to the care of probation officers only upon certificate of the physician in charge. In addition, there should be provision for mendicant blind and cripples to be taught some trade.

3. Probation officers. A system of probation officers is essential in connection with a State Farm. The admirable system by which fifty-nine volunteer probation officers serve the State of Massachu- 
setts provides that upon release on probation, the probationer report at once upon arrival at his destination to the probation officer of his district, who determines how often he shall report to him during the remainder of the time for which he was sentenced. Tickets to their destination are furnished probationers by the State.

That the State Farm and system of probation visitors tends to reduce the number of vagrants is evidenced by the experience of Massachusetts :

\begin{tabular}{|c|c|c|c|}
\hline & TOTAL AT STATE & NUMBER OF & PER CENT OF \\
\hline YEAR. & FARM. & VAGRANTS. & TOTAL. \\
\hline 1892 & 506 & 212 & 42 per cent. \\
\hline I 897 & $\ldots \ldots 528$ & 502 & 33 \\
\hline I 898 & $\ldots \ldots$ I343 & 316 & 25 \\
\hline 1903 & .... I960 & 304 & I 6 \\
\hline
\end{tabular}

Of the 59 vagrants released from the State Farm in 1903 to probation officers, only 13 were returned for violation of parole.

4. State vagrancy officer. To secure the largest benefit from a State Farm there must be at least one state vagrant officer as a member of the State Constabulary, preferably three or four, to co-operate with the local police and courts of small towns and the railroad police in securing the conviction of vagrants and trespassers and their commitment to the state institution.

The existence of a state farm encourages the courts to convict vagrants, as it abolishes the expense of additional prisoners to local authorities.

5. Incorrigible vagrants. Many, if not all, of these have illegitimate children, and society in self-defense, demands that they be segregated for life.

III. Need of uniformity. The above program, if vigorously enforced, would in a comparatively short time rid one State of vagrants, but that would simply mean driving them to another State. The problem of eradicating vagrancy is pre-eminently a national one.

I. Bertillon measurement. A bill is now (March, I904) before the Massachusetts State Legislature which provides that every prisoner under sentence as a vagrant shall be measured and described by the Bertillon method for the identification of criminals by proper persons in the service of the State. Such a law should be enacted in 
every state, and the measurements and record of every vagrant sent to a central registration bureau, similar to the National Detective Bureau at Washington, so that his record may be secured at once in any part of the country.

2. Uniform sentences should be imposed in all states.

3. The establishment of the system of probation visitors in every state is vital to its complete success in any one state.

4. Social legislation. Laws affecting the treatment of the dependant should be unified in the states, and wife desertion made an offense and extraditable.

5. The co-operation of unions must be sought in developing thrift among their members. When they emphasize this virtue and extend their organization to lower grades of labor they will save many of their members from vagrancy.

Such methods of treatment, it may be claimed, do not make sufficient provision for the "unfortunates" who are compelled to wander. The problem of unemployment is not within the scope of this paper, nor a discussion of the economic conditions and the need for mobility of labor. It is sufficiently evident, however, that in normal industrial conditions vagrancy is not due in any appreciable measure to economic causes.

The plan outlined is largely the compilation of experiences and successful methods. It has been discussed with several representatives of each class of vagrants, and without essential exception they have agreed that it provides kind and just treatment for every vagrant and a sufficiently repressive program to have dissuaded them from a life of vagabondage, had it been in force when they began their career.

\section{APPENDIX.}

Data concerning I 8 men interviewed at the Wayfarers' Iodge of the Philadelphia Society for Organizing Charity, 1902-1903:

I. Conjugal condition:

Single men 94

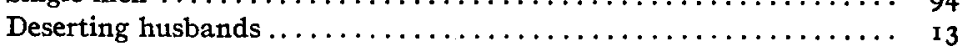

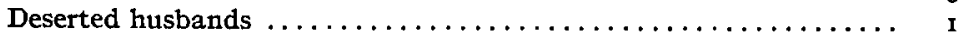

Widowers $\ldots \ldots \ldots \ldots \ldots \ldots \ldots \ldots \ldots \ldots \ldots \ldots \ldots \ldots \ldots \ldots$

Legally separated $\ldots \ldots \ldots \ldots \ldots \ldots \ldots \ldots \ldots \ldots \ldots \ldots \ldots \ldots$

Living apart from wife who remarried $\ldots \ldots \ldots \ldots \ldots \ldots \ldots \ldots$ I 
II. Ages:

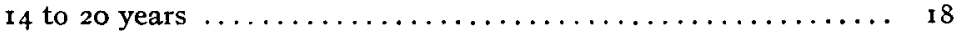

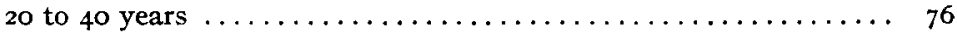

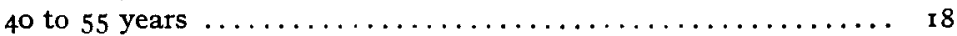

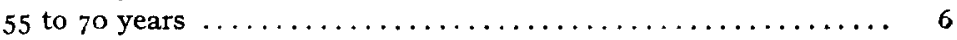

1II. Early conditions:

8 had been in orphanages and asylums.

33 lost mother before they were 16 .

24 lost father before they were 16.

8 left school under 12 .

13 left school between 12 and 14.

30 left school between 14 and 16 .

33 left school between 16 and 20 .

Of this number, 62 left voluntarily, only 23 being obliged to work to help support the family. Only ro had any technical education; 23 had served apprenticeship and learned a trade; 83 lived till I $_{2}$ to 14 in cities of 10,000 or over, and 35 in cities of less size and in the country; 68 only did not have families and relatives in Philadelphia.

IV. Character:

(a) 3 I were given a good character by their relatives and references.

37 were given an unfavorable character by their relatives and references.

(b) ro had committed petty crimes and larceny.

(c) 6 had been in prison.

(d) 57 gave at least one false address.

(e) I9 gave aliases.

(f) 24 either had or had had means in their families.

(g) 42 had homes to which they could return.

20 were wanted home by their relatives.

(h) Family religious affiliations:

Roman Catholic $\ldots \ldots \ldots \ldots \ldots \ldots \ldots \ldots \ldots \ldots \ldots \ldots \ldots$

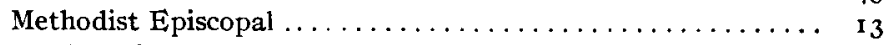

Presbyterian $\ldots \ldots \ldots \ldots \ldots \ldots \ldots \ldots \ldots \ldots \ldots \ldots \ldots \ldots$ 1 3

Evangelical Lutheran $\ldots \ldots \ldots \ldots \ldots \ldots \ldots \ldots \ldots \ldots \ldots$ r 3

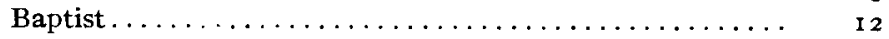

Episcopalian $\ldots \ldots \ldots \ldots \ldots \ldots \ldots \ldots \ldots \ldots \ldots \ldots \ldots$

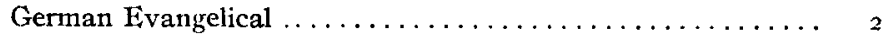

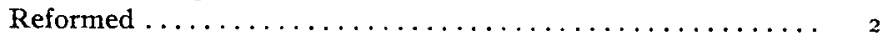

United Presbyterian $\ldots \ldots \ldots \ldots \ldots \ldots \ldots \ldots \ldots \ldots \ldots$ I

Congregational .................... I

I IO

All but eight were from families with religious inclinations, but the majority of the men attended only the Sunday Breakfast Association.

V. General physical condition:

112 good; 6 bad. 
VI. Nativity:

United States: Both parents white, 88 .

One parent colored, I.

One parent foreign, $I$.

Great Britain: England 4, Scotland I, Ireland 6-I I.

Germany, I I ; Italy, 2.

France, Belgium, Scandinavia and Russia, each I.

VII. Literacy:

r o could read and write, and 2 read English and read and write German;

6 could neither read nor write English.

VIII. Occupations:

34 occupations were represented.

Laborers . . . . . . . . . . . . . . . . . . . .

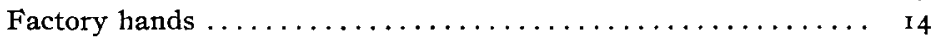

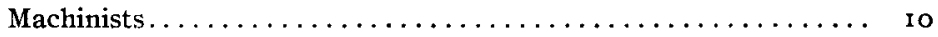

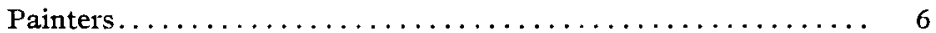

Farm hands, iron moulders, printers, hostlers, each......... 4

Sailors, plumbers, cooks, bakers, each.............. 3

Coopers, line riggers, boiler-makers, tinsmiths, peddlers, miners, each 2

Driller, porter, wall paperer, packer, jeweler, electrician's helper, telegrapher, carpenter, bell boy, railroad brakeman, shipbuilder, chemist, student, fireman, each .............. r

IX. Work records:

I 6 out of i 8 had voluntarily given up employment once or more frequently during the six months previous to their interview. The average of the highest weekly wage earned by the men was $\$ 13.93$, an average brought up by the wages of a few skilled and formerly professional men.

'The average of the longest time worked by 79 of the men at any one place during the preceding five years was 12.22 months, and the average number of employers of 87 of them during the preceding two years was $6.3 \mathbf{I}$.

References were secured from one or more employers of 75 men, 38 men were stated to be good, expert workmen, and 37 medium or inefficient.

The employers of 27 stated they could get work at once if temperate, and 13 other men refused assistance to secure employment.

3 were members in regular standing of some union; 4 had been members, but their membership had lapsed.

45 left when they learned an effort was being made to secure them employment; 3 reported securing employment themselves; 12 were offered work upon our request by a previous employer.

3 I men were secured employment in all; I I of these dropped work in a short time, varying from a few days to a month; 6 were entirely satisfactory. 
7 refused work when offered on the plea that it was too hard, or that as members of a union they would not accept the work.

Subjective Causes of Lack of Employment.

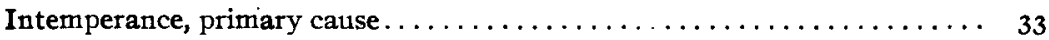

Intemperance, secondary cause $\ldots \ldots \ldots \ldots \ldots \ldots \ldots \ldots \ldots \ldots \ldots \ldots$

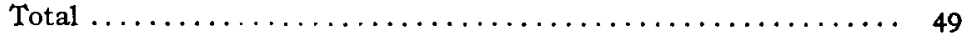

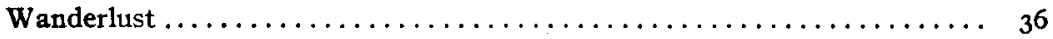

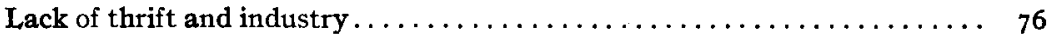

Dishonesty and other moral defects $\ldots \ldots \ldots \ldots \ldots \ldots \ldots \ldots \ldots \ldots \ldots \ldots$

Licentiousness $\ldots \ldots \ldots \ldots \ldots \ldots \ldots \ldots \ldots \ldots \ldots \ldots \ldots \ldots \ldots \ldots$

Treatment Needed.

Commitment to State Farm.......................... 36

Commitment to Industrial School ....................... 24

Should be taken charge of by relatives $\ldots \ldots \ldots \ldots \ldots \ldots \ldots \ldots \ldots \ldots$ r 5

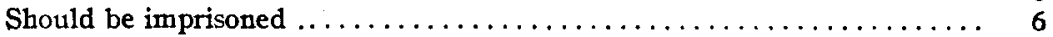

Should be taught thrift by hardship $\ldots \ldots \ldots \ldots \ldots \ldots \ldots \ldots \ldots \ldots, \quad 18$

Should be given institutional treatment $\ldots \ldots \ldots \ldots \ldots \ldots \ldots \ldots \ldots \ldots, 4$

Should be returned to native country under immigration laws $\ldots \ldots \ldots \ldots, 4$

Should have been helped to employment. .................... II

Philadelphia.

Benjamin C. Marsh. 